\title{
PEDAGOGICAL PSYCHOLOGY IN THE RESEARCH ACTIVITIES OF STEFAN BALEY
}

\author{
MYKHAILO PODOLIAK
}

\begin{abstract}
The article is dedicated to the revealing of the problem of pedagogical psychology in research activities and works of Ukrainian and Polish researcher, pedagogue, psychologist, philosopher Stefan Baley (1885-1952). The relevance of the theme is conditioned by the active reforming processes of Ukrainian educational system, in which ideas of the scholar can be widely used as well as his thoughts, ideas and research of child psyche. The article gives biographical data of the scholar and emphasizes his field of work as well as main works. The principles, subject and aims of pedagogical psychology according to Stefan Baley are presented in the article. The article analyses the notion of education and educational relations according to the researcher as well as the process of education and its types, namely: analytic and empiric education, systematic and global education. The problem of a child education in a group is presented in the article i.e. school class. The author emphasized the actuality and expediency of practical usage of ideas and research activities of Stefan Baley at the current stage of Ukrainian school system reforming, according to the results of comparison between the problematics of Stefan Baleys' research activities in the sphere of pedagogical psychology and K. Seifert and R. Sutton.
\end{abstract}

Keywords: pedagogical psychology, Stefan Baley, education, learning, child, school.

\section{INTRODUCTION}

It has been stated that the modern Ukrainian educational system currently is being under the active stage of reforming that presupposes its humanization and orientation for child centric education [6]. These processes presuppose taking into account physical, psychical features of children, their interests, individual possibilities and needs. The similar orientation is seen in some legal acts in the educational sphere of Ukraine, such as: Law of Ukraine "About education", "About childhood protection", National strategy of Ukrainian educational system development for the period till 2021, "About the social work with children and youth" etc. These legislative acts focuse on the full and comprehensive development of a child; the necessity and importance of childhood in the process of a personality formation; main tasks in the content, forms and methods of educational process organization that are based on the principles of child centrism. One should use not only pedagogy, but also psychology as well to perform these functions with the maximum effect. These two fields of science show full image of the development processes of a child, describe this processes and influence on the education of useful for society personality. Pedagogy and psychology, in the context of a child development, are 
interconnected and com plementary subjects, with the help of which pedagogue or educators effectively perform and control educational processes of a child.

It has been noted that the importance of pedagogical psychology in educational process of a child was underlined by the famous global scholars, such as: E. Thorndike, J. Herbart, H. Rice, G. Hall, V. James, D. Dewey, L. Vygotsky and others [5]. The modern development of pedagogical psychology can be divided into certain trends, among which can be singled out the following: the research of teaching; educational psychology; psychology of school subjects; methodology; evaluation etc. Stefan Baley (1885-1952) belongs to the list of prominent scholars of pedagogical psychology as well. He was one of the first to begin researching this field of science on the territory of the Eastern Europe. The works of Stefan Baley are useful for modern Ukrainian scholars and can be actively used in conditions of current active reforming processes and improving of Ukrainian educational system, especially school.

The aim of the article is to present and interpret pedagogical psychological ideas of Stefan Baley and determine of notional and categorical apparatus of pedagogical psychology according to the scholar; describe ways of practical usage of his ideas in the current process of Ukrainian educational system reforming.

\section{ANALYSIS AND DisCUSSION}

The prominent Ukrainian and Polish scholar was born on February $4^{\text {th }}, 1885$ in the village of Velyki Birky, Ternopil region. He studied psychology and philosophy at the Philosophical Faculty of Lviv University, where he was able to listen to the lectures of Polish philosopher Kazimierz Twardowski (1866-1938). Having graduated from the University, Stefan Baley began to work as a teacher of psychology and logics in Ukrainian gymnasiums of Lviv, Ternopil and Peremysl. He obtained the degree of Doctor of Philosophy, under scholarly supervision of K. Twardowski in 1911 in Lviv University. He received a government grant for further education of scientist and headed for Germany, France and Austria to study and conduct research on the basis of this degree. He attended lectures of the professor Karl Stum pf in Berlin and he worked in psychological and physiological institute of Berlin University. Stefan Baley studied in Paris, Sorbonne and in Vienna as well.

Upon returning to Ukraine, Stefan Baley wrote several works of psychology and philosophy and after the study (1917-1922) he obtained the Doctor's degree. Stefan Baley actively worked in Polish scientific circles and publication houses. He took an active part in the activity of Polish Philosophical Society in Lviv. He worked in the Secret Ukrainian University in 1922-1924 and due to that fact, he received a refusal of employment at Lviv University. However, Stefan Baley got a job at Warsaw University in 1928 with the help of K. Twardowski and became a head of the department of pedagogical psychology in Warsaw University. He was the member and organizer of philosophical, psychological and pedagogical state and public institutions and organizations, such as: director of the Institute of Psychology of Education at the University of Warsaw; Head of the State Teachers' Institute; the Pedagogical Institute of the Union of Polish Teachers; the psychological office and many other professional institutions. The scholar was elected a member of the Warsaw Philosophical Society; the Warsaw Scientific Society; the chairman of the Commission of the Pedagogical Scientific Society; awarded the Order of the Renaissance of Poland. He was a member of the Polish Academy of Sciences.

The scholarly heritage of Stefan Baley consists of numerous works, written in Polish, Ukrainian and German from medicine; psychology; philosophy; logics; pedagogics; the works on the psychology of creation of Taras Shevchenko personality; the first printed books on psychology and logics; theoretical articles on philosophy and ethics; scientific research of global philosophy etc. Marat Vernykov noted that the scholarly works of the professor cannot be counted by the number of his works, but their fundamentality and information saturation. He said that the works of Stefan Baley consist of great number of pages and combine theoretical and experimental experience [3]. The most significant works of the scholar include: Psychology of the age of ripening (1931); Essays on psychology in connection with the development of the child's psyche (1935); Essay on the psychology of education (1938); 
Characterology and typology of children and young people (1946); Essay of Psychology (1922); Essay of Logic (1923) and many others.

Polish scholarly literature writes about Stefan Baley as a co-creator of Polish pedagogical psychology or psychology of education. However, while staying and working in Poland, the professor did not cease to maintain ties with Ukrainian scholars.

The scholarly activity of Stefan Baley is characterized by the psychological and pedagogical studies. The clear division between pedagogical and psychological views of the scholar cannot be found. The scholar used knowledge on pedagogics, psychology, sociology and medicine while researching a child and its development. The key object of Stefan Baley's scholarly activity of is child and childhood. He researched them in a complex, emphasizing the interdependence of psychological and physical development of a child.

Stefan Baley singled out its aim i.e. psychological analysis of educational processes while researching pedagogical psychology. Moreover, he stated that pedagogical psychology conducts research of the psychological structure of education. It has been noted that the subject of this science is not only a child, but also the process of its education [1, p. 11]. The principles of Stefan Baleys' pedagogical psychology takes into account the individuality of a child, its interests, needs in the process of its education. Pedagogical psychology according to the researcher is not only theoretical science, but also practical, since theoretical results can be used in the practice and practical activity should be based on a certain theoretical basis [1, p. 16].

Stefan Baley did not provide clear differences between pedagogical psychology and pedagogy while analyzing the relation between them. He noted that they are closely interconnected and study a child as a complex: "Pedagogue, which study the theory of education should often use certain psychological notions and address to the psychological rules and notions and thus, he switched in his researches from the pedagogical sphere into pedagogical psychological." [1, p. 16]. The same way a psychologist can switch from the psychological sphere to pedagogical psychological while researching educational influences.

Stefan Baley claimsd that the process of education takes place in the close connection with psychology: "Thus, there is no doubts that in educational phenomenon takes place certain phenomena and psychological dispositions. And so, talking about the sources of education we understand here intellect, imagination, memory, interest etc. i.e. certain psychological dispositions." [1, p. 7-8]. Moreover, the scholar noted that during the process of physical education of a child psychological education played a great role: "Taking into account the fact that the managers of bodies exercises have hope with their help to elaborate in their fosterlings certain psychological properties, such as courage and discipline." [1, p. 8]. The notion of education Stefan Baley understood as the form of education resulting in knowledge and skills.

Stefan Baley emphasized the educational relations while describing the process of child's education. The example of such relations are the relations between a head person with a subordinate person or school teacher with a student. Educational relations are very often connected with other social relations and that is mentioned in the works of the scholar as well. For example, one can spot such social relations as: friendliness or hostility, leadership and submission, love or struggle, etc. in the relations between a teacher and pupil. Stefan Baley states on the independence of educational relations from other social relations and the subject of these relations, i.e. educator and fosterling: "The educator combines with the fosterling some relations which means that educator conducts certain educational actions that should be independent from other types of social relations." [1, p. 340].

The other type of relation, Stefan Baley emphasizes on, is outside educational relationship. Such kind of relations should be united, so that they can help each other the scholar claims [1, p. 343]. Educational relations can be both, separated from the social ones and should rely and use them. Managing and restriction of some social relations could have negative effect in the process of child education, since some psychological dispositions would be better developed and other could be weaker. Stefan Baley treated educational relations as the combination of certain social relations, which 
have constant influence on the process of personality formation. Thus, his ideas can witness that the scholar gives one of the leading role to the society and environment in the process of a child education.

Stefan Baley treated education in a group not only as the improvement of certain qualities of a human, but as the adjustment of the human's psyche to the collective or social life. The preparation to this working environment should take place in young age, when small children gather together in certain groups since a hum an should work in his future inside some social group. Education in a group adapt psyche of a child to the further social life. The important component of a group is introducing some work or activity that should be done to all children at the same time. The thoughts, interests and feeling of other members of this group should be respected and taken into account by other members and teachers as well during such work or activities. The organization of group's own work and its usefulness for such group is also of great importance. Education in a group should develop leader qualities of a child's psyche from one side, and obeying rules and executing orders - from the other. This information can be used by the teachers and educators, while managing the working process in their class or group. As it is seen from the ideas of the scholar, teachers should pay attention not only to the material they should present to children, but they should actively participate in the process of a child's personality development as well. Teachers should educate and promote such behavior and qualities in a child that will be useful in modern society states Stefan Baley.

It should be mentioned on the Stefan Baleys' research of the problem of child education in school in the context of the child's education analysis in a group. His research presents the most important structural elements of the school education, i.e.: composing of the school program, the role of school psychologist and conducting of him the psychological guardianship of pupils, teacher and their functions, education in a school class, evaluation of pupils, notion of education and its types etc. It is important that the scholar provides not only the results of his own research activities, but also the methodical recommendations which still remain actual, and in particular in the current time of the Ukrainian educational system reformation. The scholar, for example, stressed upon the importance of the school psychologist in a school. His aim is to conduct psychological analysis of the school program, affiliation of the materials and methods to the psychological state of a pupil and his interests and needs. If in an Ukrainian school had been conducted in an appropriate way the psychological affiliation of a pupil, proposed by Stefan Baley, the unpleasant results or the activity of so-called "Death Groups" (blue whale, silent house etc.) could have been omitted.

The evidence of the actuality of Stefan Baleys' works is observed while com paring the content of his main works on pedagogical psychology with the book of the famous scholars Kelvin Seifert and Rosemary Sutton "Educational Psychology", which was published in 2009 [5]. One can notice the similarity of the topics of research and methodic recommendations to teachers while comparing these woks. The authors of the book emphasize on the importance of taking into account the psyche of pupils, their interests and needs, and it is similar to the child centric model of children education, formed by Stefan Baley, despite the fact that his ideas were mentioned more than 70 years ago.

The psychological pedagogical ideas of child education in family can be widely used by parents nowadays. His famous table of the psychological development of a child, divided according to the age principle can be of great use for teachers, parents, scientists, educators and many other professionals. A parent or some other interested person can easily adapt his educational process to the child psyche, so that to have the maximum effect while reading and analyzing Stefan Baleys' works. Stefan Baley described a child psyche and its development in detail, mentioning at the same time its physical development. He treated education as certain actions that produce and form certain child psyche peculiarities.

Stefan Baley included the ability of a human to education, heredity, intellectual dispositions, emotional and will dispositions, instincts, interests, instinct of self-education and imitation to the sources of education.

The ability for education manifests in each person individually. In this context, such psychological dispositions take part: intellect, attention, memory, fantasy, ability to work etc. They include all psychological dispositions, which general psychology divides a human psyche: "It is all kind of 
psychological dispositions, which general psychology divides a human psyche. They are relevant correspondences in the mind and together with feelings, needs, aspirations and instructions they are marked as source, from which education is beginning and as a material, which it forms as well." [1, p. 72]. The research of other scholars show that the ability of a human to be educated is decreasing, in average, beginning from 20 years of age.

The heredity, as a source of the educational process, the scholar explained using psychology, namely he researched the possibility of some psychological features of character inheritance from parents to children. He stated that some psychological features in children are not well developed at the moment of their birth, but they can be in a form of makings, from which all skills, psychological features will be developing in the process of child's education [1, p. 76].

While researching intellectual and emotional will dispositions as sources of education, Stefan Baley explained and described the role of each of them in the educational process. He emphasized the importance of intellect development in a child and gave useful ideas for teachers and parents in his works on educational psychology.

Instincts can have different influence on the educational process according to the scholar. One of them has stronger influence while the other is weaker. Instincts differ according to the sphere of influence in the educational process, i.e. ones are more important for coeducation of boys and girls and others for self-education. The instinct of interest as a component of human instincts, plays crucial role in education, since it determine tempo and the direction of the educational process; for example, a small child is interested in the language of adults, but he cannot talk, and the more he is interested in the process of speaking, the faster he will learn it. The interest of children is observed in games and here one can track the development or presence of certain instinct.

The main component of interest is interest in learning something new. If one can stimulate this interest, the interest for education could occur and thus, for self-development as well. Thereby, the instinct of interest is in close relation with the instinct of education and learning. The scholar mentioned that these games are in close relations and supplement each other: "Truly it is known, that a child game and education remain in close relations between each other. A game gives a child ability to study, but the wrong would be the statement that education of a small child in any case is collateral product of a game." [1, p. 134].

Stefan Baley researched and published the notion of education of children and its types in the work: "Educational psychology in writing". He worked out and published the explanation of this term, given by many scholars. The very notion of education, Stefan Baley said, has broader meaning than the notions training and exercises execution. Training and education he explains the following way: "About the training it is first of all where the execution of exercises for increasing of the efficiency of some function, thus the developing and improving of something that the person has already reached; the notion of education also includes attem pts that allow to reach some results in general." [1, p. 173].

While researching the process of education, the scholar propose to pay attention on its product and qualitative component of this product and for the duration of the very process of education. While researching qualitative and quantitative indicators of education and the necessary time for its achievement, Stefan Baley composed diagrams of the processes of education and training. These diagrams consisted of different kinds of processes of education and time that was necessary for such kind of processes.

Stefan Baley divided the forms of education into: scientific education, education with the help of mistakes, movement education, education through understanding, education through imitation, collateral education. Stefan Baley in detail described each form of education and provided samples of such educations. Moreover, he described in detail the way he did such experiments, so that a scholar could do it by himself. As the best example can be taken the education through mistakes. Stefan Baley showed labyrinths, which children were solving and this that the way he explained how the education through mistakes helped educate children.

Stefan Baley emphasized the importance of the educational process through imitation, which, according to the scholar, had sometimes character of collateral or unintended learning. In this form of 
education he presented education through mistakes, since a certain person wants to reach the same success as the collateral person and he makes mistakes and attempts to reach such kind of success. The education through imitation, according to the scholar is harder than reaching such kind of result by a child himself.

This information can be used in the modern process of Ukrainian education reforming. Scholars, teachers and educators can learn the forms of education made by Stefan Baley and use some into practice. They can adjust their educational process to elaborate useful features of character in a child. However, still teachers use some abovementioned forms i.e. when they are conducting lessons and ask pupils to repeat after them, and this is education through imitation.

Besides the forms of education and training, Stefan Baley researched types of education and divided them as follows:

1. Empirical - the education through different experiments and experiences. This type of education can be of great use in teaching such subject as: biology, chemistry, physics etc. Modern teachers of these subjects should use more visual and practical experience in the teaching process than theoretical;

2. Systematic - education with the help of understanding. This type of education can be used by teachers of humanities and sciences, because every presented material needs to be not crammed by pupils, but understood, so that to make it useful;

3. Analytical education takes part when a person tries to learn by thinking and analyzing presented information;

Global education takes part when pupil learn information in general, without taking into account details of the material or subject.

\section{CONCLUSIONS}

Stefan Baley treated the notion of education using psychology. Learning is a complex element of the process of education, the results of which are gained through knowledge and skills according to the researcher. The scholar explained the relations between psychology and pedagogy and stressed on the relevance of pedagogical psychology study. The aim of this science is to conduct psychological analysis of the educational process and the psychological analysis of a child. The researcher in detail described the examples of educational relations, which he explained as a part of social relations. The important part in the process of education is sources of education. Stefan Baley divided them into: intellectual dispositions, emotional will dispositions, ability of a human to education, heredity, instincts, interest, instinct of self-study and imitation. The scientist divided education into empirical, systematic, analytical and global. The perspective of further research is in describing and analysis of psychological ideas of Stefan Baley and singling out his psychological concept.

\section{REFERENCES}

[1] Baley S. Psychologia Wychowawcza w Zarysie [Educational Psychology in Essay]. Książnica-Atlas, LwówWarszawa, 1938. (in Polish)

[2] Baley S. Zarys Psychologji w Zwiazku z Rozwojem Psychiki Dziecka [Essay on psychology in connection with the child's psyche development]. Książnica-Atlas, Lwów-Warszawa, 1935. (in Polish)

[3] Baley S. Collection of works in 5 volumes and 2 books, Vol. 2. Lvivska politekhnika, Lviv, 2009. (in Ukrainian)

[4] Berliner David. The 100-Year Journey of Educational Psychology. Available at: http://www.wou.edu/ girodm/611/Berliner_100years.pdf

[5] Seifer K., Sutton R. Educational Psychology. Second Edition. Available at: https://www.saylor.org/site/wpcontent/uploads/2011/04/Educational-Psychology.pdf 
[6] Lyashenko O.I. Priorities of development of Ukrainian education in the context of educational reform. Collection of Scientific Papers Kamianets-Podilskyi National Ivan Ohiienko University. Pedagogical Series, 22 (2016), 39-42. doi: https://doi.org/10.32626/2307-4507.2016-22.39-42 (in Ukrainian)

[7] Podoliak M. Stefan Baley - a cross-cultural scientist. Kwartalnik Pedagogiczny, 3 (237) (2015), 92-102.

[8] Vintiuk Yu. Theoretical basis of psychological views of Stefan Baley. Pedagogic and Psychology of Professional Education, 1 (2016), 169-180. Available at: http://nbuv.gov.ua/UJRN/Pippo_2016_1_20 (in Ukrainian)

[9] Zebrowska M. Wspomnienia posmiertne: Stefan Baley (1885-1952) [Posthumous Memoring: Stefan Baley (1885-1952)]. Rocznik Towarzystwa Naukowego Warszawskiego, 45 (1952), 89-92. (in Polish)

Address: Mykhailo Podoliak, Stepan Gzhytskyi National University of Veterinary Medicine and Biotechnologies Lviv, 50, Pekarska Str., Lviv, 79010, Ukraine.

E-mail: misha.podol@bigmir.net

Received: 18.01.2019; revised: 22.03.2019.

Подоляк Михайло. Педагогічна психологія у дослідженнях Степана Балея. Журнал Прикарпатського університету імені Василя Стефаника, 6 (1) (2019), 142-148.

Стаття присвячена представленню педагогічної психології в науковій діяльності та роботах українського та польського дослідника, педагога, психолога, філософа Степана Балея (1885-1952). Актуальність теми обумовлена активними процесами реформування української освітньої системи, в яких широко можна використовувати ідеї вченого, пропозиції та дослідження дитячої психіки. У статті наведені біографічні дані вченого і підкреслюється його сфера діяльності, а також основні наукові праці. Автором представлено принципи, предмет і цілі педагогічної психології Степана Балея. Проаналізовано поняття виховання та виховних відносин, наведено поділ виховних відносин на такі типи: аналітичне та емпіричне виховання, систематичне та глобальне виховання. Висвітлено проблему виховання дитини в групі, а саме у шкільному класі. Наголошено на актуальності та доцільності практичного використання ідей та дослідницької діяльності Степана Балея у контексті сучасного реформування української шкільної системи. У статті здійснено порівняння проблематики досліддницької діяльності Степана Балея у сфері педагогічної психології і К. Сейферт і Р. Саттон.

Ключові слова: педагогічна психологія, Степан Балей, виховання, навчання, дитина, школа. 